\title{
Chemical composition including content of amino acids, minerals and alkaloids in seeds of three lupin species cultivated in Poland
}

\author{
Justyna Wasilewko and Lucyna Buraczewska \\ The Kielanowski Institute of Animal Physiology and Nutrition, \\ Polish Academy of Sciences \\ 05-110 Jablonna, Poland
}

(Received 16 September 1998; accepted 19 November 1998)

\begin{abstract}
Seeds of six cultivars of yellow lupin (Lupinus luteus L.), three of white lupin (Lupinus albus L.) and four of narrow-leaved lupin (Lupinus angustifolius L.) were analysed for the content of nutrients and antinutritional factors. Batches of seeds harvested during threc consecutive ycars were analysed for each cultivar. Seeds of yellow lupin cultivars contained significantly $(\mathrm{P}<0.05)$ more protein $(43.5 \% \mathrm{DM})$, cystine $(2.2 \mathrm{lg} / \mathrm{l} 6 \mathrm{gN})$, ash $(5.4 \% \mathrm{DM})$, crude fibre $(16.4 \% \mathrm{DM})$ and alkaloids $(510-1300 \mathrm{mg} / \mathrm{kg} \mathrm{DM})$ than seeds of white and narrow-leaved lupins. Seeds of white lupin had significantly more fat $(10.5 \% \mathrm{DM})$, manganese $(670 \mathrm{mg} / \mathrm{kg} \mathrm{DM})$, toxic alkaloids $(600-950 \mathrm{mg} / \mathrm{kg}$ $\mathrm{DM}$ ) and more threonine and isoleucine ( 3.77 and $4.39 \mathrm{~g} / 16 \mathrm{~g} \mathrm{~N}$, respectively) as compared to other species. The contents of lysine, cystine and isoleucine in yellow lupin protein and that of threonine in white and narrow-leaved lupin seeds $(\mathrm{g} / 16 \mathrm{~g} \mathrm{~N})$ were negatively correlated with the protein content of seeds.
\end{abstract}

KEY WORDS: lupins, nutrients, amino acids, minerals, alkaloids

\section{INTRODUCTION}

Sweet lupin seeds are a potentially important source of protein for monogastric animals. The nutritive value of lupin depends mainly on the content of both protein and oil. The latter is especially high in white lupin seeds. Lupin oil is not only an energy source, but it contains essential unsaturated fatty acids (Hill, 1977). 
Good adaptability to various climatic and soil conditions qualifies lupin as a homegrown substitute for imported soyabean meal. Yellow, white and narrowleaved lupins are grown in Poland. Cultivars with determined type of growth and more uniform ripening were obtained within each species over recent years (Święcicki et al., 1997). Modifications of the lupin genotype resulting in the improvement of agronomical traits may affect the content of nutritionally important components. Therefore, the main objective of the undertaken study was to evaluate chemical composition of 13 recently grown lupin cultivars representing three species. Only low alkaloid varieties, cultivated for feeding purposes, were analysed.

\section{MATERIAL AND METHODS}

Seeds of six cultivars (Juno, Popiel, Amulet, Radames, Cybis, Manru) of yellow lupin (Lupinus luteus L.), three cultivars (Hetman, Bardo, Wat) of white lupin (Lupinus albus L.) and four cultivars (Emir, Sur, Saturn, Polonez) of narrow-leaved lupin (Lupinus angustifolius L.) cultivated in Poland were analysed in this study. Cultivars Juno, Popiel, Radames, Manru, Hetman and Saturn are recently bred ones, some of them with introduction of genes controlling self-completing or thermoneutrality. The lupins were grown in the central and middle-west regions of Poland. The tested seeds were provided by the plant breeding stations such Wiatrowo, Kosieczyn and Strzelce, where standard cultivation technologies are applied. The samples of each cultivar were collected and analysed for three consecutive years. The average yield of yellow and narrow-leaved lupin seeds was about $2 \mathrm{t}$ and of white lupin - about $3 \mathrm{t} / \mathrm{ha}$, except for the year 1992, when water deficiency decreased yields by about $60 \%$.

\section{Analytical methods}

Dry matter (DM), nitrogen, ether extract (EE), ash (A) and crude fibre (CF) were analysed using standard methods (AOAC, 1990). Amino acids analysis of lupin seeds was performed with a Beckman 6300 High Pressure Amino Acid Analyzer using modified procedures according to Buraczewska and Buraczewski (1981). The contents of neutral detergent fibre (NDF), acid detergent fibre (ADF) and acid detergent lignin (ADL) were determined according to the Van Soest and Wine (1967) and Van Soest (1973) methods. The quinolizidine alkaloids content was analysed according to Wysocka et al. (1989) using a thin layer chromatography. The minerals: $\mathrm{Ca}, \mathrm{K}, \mathrm{Mg}, \mathrm{Na}, \mathrm{Fe}, \mathrm{Mn}, \mathrm{Zn}, \mathrm{Cu}$ of lupin seeds were analysed using Atomic Absorption Spectrometer - Philips PU 9100X (Philips Scientific 1988). Phosphorus was determined by AOAC procedure (1990). 


\section{Statistical analysis}

The average values and standard deviations were calculated for three analysed samples representing three consecutive years. Multi-way analysis of variance was carried out on the results using year of harvest and cultivar of lupin as an independent variable. All calculations were made using Statgraphics Plus ver. 7.0 (1993).

\section{RESULTS AND DISCUSSION}

Seed composition (Table 1) was influenced neither by the year of harvest nor by lupin cultivar within the species. Similarly, no significant differences were found

TABLE 1

Chemical composition of lupin cultivars harvested in 1991-1994, \%DM

\begin{tabular}{|c|c|c|c|c|c|c|c|c|c|}
\hline \multirow[t]{2}{*}{ Cultivars } & \multirow{2}{*}{$\begin{array}{l}\text { Weight of } \\
1000 \text { seeds,g }\end{array}$} & \multirow{2}{*}{ DM } & \multirow{2}{*}{$\mathrm{CP}$} & \multirow{2}{*}{$\mathrm{EE}$} & \multirow{2}{*}{ Ash } & \multicolumn{4}{|c|}{ Fibre fraction } \\
\hline & & & & & & CF & $\mathrm{ADF}$ & NDF & $\mathrm{ADL}$ \\
\hline \multicolumn{10}{|c|}{ Lupinus luteus: } \\
\hline Juno & 131 & 89.8 & 42.5 & 5.3 & 5.3 & 16.6 & 21.2 & 25.4 & 2.2 \\
\hline SD & 1 & 1.49 & 1.31 & 0.15 & 0.23 & 2.13 & 2.48 & 2.00 & 0.50 \\
\hline Popiel & 135 & 89.4 & 44.1 & 5.3 & 5.1 & 15.2 & 20.0 & 24.1 & 1.8 \\
\hline SD & 3 & 2.14 & 3.75 & 0.20 & 0.95 & 2.17 & 2.86 & 3.27 & 0.32 \\
\hline Amulet & 122 & 89.8 & 44.4 & 4.6 & 5.4 & 16.7 & 21.3 & 25.7 & 1.9 \\
\hline $\mathrm{SD}$ & 13 & 3.12 & 0.90 & 0.06 & 0.82 & 0.82 & 0.79 & 0.12 & 0.40 \\
\hline Radames & 137 & 89.6 & 42.2 & 5.7 & 5.7 & 16.6 & 21.7 & 25.9 & 2.2 \\
\hline SD & 1 & 0.92 & 4.48 & 0.57 & 0.72 & 1.61 & 1.61 & 1.77 & 0.44 \\
\hline Cybis & 132 & 90.2 & 44.1 & 5.6 & 5.4 & 15.8 & 19.7 & 24.6 & 1.5 \\
\hline SD & 11 & 2.39 & 2.30 & 0.15 & 0.51 & 0.81 & 1.09 & 1.36 & 0.15 \\
\hline Manru & 127 & 90.0 & 43.6 & 5.5 & 5.3 & 17.3 & 21.7 & 26.8 & 2.8 \\
\hline SD & 26 & 0.15 & 5.62 & 0.17 & 0.21 & 1.23 & 2.22 & 0.61 & 1.34 \\
\hline \multicolumn{10}{|c|}{ Lupinus albus: } \\
\hline Hetman & 331 & 90.9 & 37.4 & 10.8 & 4.6 & 13.0 & 17.9 & 21.6 & 2.5 \\
\hline $\mathrm{SD}$ & 107 & 1.05 & 4.17 & 0.96 & 0.55 & 1.18 & 2.27 & 2.46 & 0.67 \\
\hline Bardo & 285 & 90.3 & 35.1 & 10.5 & 4.0 & 13.8 & 19.5 & 23.5 & 2.6 \\
\hline SD & 52 & 2.05 & 3.67 & 2.21 & 0.23 & 1.82 & 3.33 & 1.72 & 0.26 \\
\hline Wat & 255 & 92.4 & 30.7 & 10.2 & 4.3 & 15.6 & 20.7 & 25.3 & 3.1 \\
\hline SD & 17 & 0.31 & 1.69 & 0.59 & 0.80 & 0.44 & 0.75 & 2.63 & 0.49 \\
\hline \multicolumn{10}{|c|}{ Lupinus angustifolius: } \\
\hline Emir & 148 & 91.6 & 32.5 & 6.8 & 4.0 & 14.2 & 19.1 & 23.7 & 1.7 \\
\hline SD & 41 & 1.05 & 1.43 & 0.31 & 0.26 & 1.45 & 1.08 & 2.30 & 0.25 \\
\hline Sur & 120 & 90.8 & 31.6 & 6.3 & 4.2 & 16.6 & 22.2 & 26.9 & 2.2 \\
\hline SD & 17 & 0.49 & 2.86 & 0.49 & 0.29 & 0.80 & 1.76 & 0.40 & 0.35 \\
\hline Saturn & 168 & 91.3 & 34.6 & 5.9 & 4.3 & 15.8 & 21.2 & 25.2 & 2.0 \\
\hline $\mathrm{SD}$ & 5 & 0.68 & 1.42 & 1.10 & 0.29 & 1.42 & 1.85 & 1.92 & 0.47 \\
\hline Polonez & 154 & 92.4 & 34.1 & 5.5 & 3.9 & 15.1 & 20.8 & 24.5 & 1.9 \\
\hline $\mathrm{SD}$ & 17 & 0.81 & 0.55 & 1.03 & 0.42 & 0.94 & 0.95 & 1.10 & 0.61 \\
\hline
\end{tabular}


TABLE 2

Chemical composition of seeds of three lupin species harvested in 1991-1995, \%DM

\begin{tabular}{|c|c|c|c|c|c|c|c|c|c|}
\hline \multirow[t]{2}{*}{ Species } & \multirow[t]{2}{*}{$\mathrm{n}$} & \multirow{2}{*}{$\begin{array}{c}\text { Weight of } \\
1000, \mathrm{~g}\end{array}$} & \multirow[t]{2}{*}{$\mathrm{CP}$} & \multirow[t]{2}{*}{$\mathrm{EE}$} & \multirow[t]{2}{*}{ Ash } & \multicolumn{4}{|c|}{ Fibre fractions } \\
\hline & & & & & & $\mathrm{CF}$ & ADF & NDF & $\mathrm{ADL}$ \\
\hline L. luteus & 18 & $130^{a}$ & $43.5^{b}$ & $5.3^{3}$ & $5.4^{b}$ & $16.4^{\mathrm{h}}$ & 20.9 & 25.4 & 2.1 \\
\hline L. albus & 9 & $290^{b}$ & $34.4^{\mathrm{a}}$ & $10.5^{\mathrm{c}}$ & $4.3^{a}$ & $14.1^{a}$ & 19.4 & 23.5 & 2.7 \\
\hline L. angustifolius & 12 & $146^{+}$ & $33.2^{\mathrm{a}}$ & $6.3^{b}$ & $4.2^{\circ}$ & $15.5^{\mathrm{ab}}$ & 20.8 & 25.3 & 1.9 \\
\hline
\end{tabular}

$\mathrm{a}, \mathrm{b}-\mathrm{P}<0.05$

between the modern (new bred) and the older cultivars. Comparison of the composition of three lupin species (Table 2) showed interspecific significant differences in the seed weight and the level of many seed components.

\section{Weight of seeds}

The mean weight of one thousand of yellow lupin seeds ranged from $122 \mathrm{~g}$ (Amulet) to $137 \mathrm{~g}$ (Radames) and did not differ statistically among cultivars. Among the yellow lupin cultivars the greatest variability in weight of seeds between the years was found in Manru variety. Seeds of white lupin cultivars showed a greater weight variability, especially Hetman, than other species. The weight of one thousand seeds of narrow-leaved lupin was from 120 (Sur) to $168 \mathrm{~g}$ (Saturn) and it did not differ significantly among cultivars.

Among three lupin species, the weight of one thousand seeds of white lupin was greater $(260 \mathrm{~g})$ than those of yellow $(130 \mathrm{~g})$ and narrow-leaved lupins $(146 \mathrm{~g})$ $(\mathrm{P}<0.05)$. These data are in agreement with the results of Brillouet and Riochet (1983), who reported large differences in the seed weight among lupins. Weather conditions during a plant maturation influence the size and weight of lupin seeds. This correlates with the yield which can be decreased by about $20-30 \%$ in dry years (Aniszewski, 1993).

\section{Crude protein}

In seeds of yellow lupin cultivars, the crude protein level was high and ranged on average from 42.2 to $44.4 \%$ DM. In white lupin cultivars the variation was greater and was: from 30.7 in Wat to $37.4 \%$ DM in Hetman but the differences were not statistically significant. Manru and Hetman showed the greatest variability between the years in protein content among the yellow and white lupins, respectively. In narrow-leaved lupin seeds, the crude protein ranged from 31.6 (Sur) to $34.6 \%$ DM (Saturn).

Among the tested species the highest protein content was determined for yellow lupin seeds, what supports other findings (Hill, 1977; Pagowska, 1990, 1993). 


\section{Ether extract}

In seeds of yellow lupin cultivars, the ether extract content was between 4.6 (Amulet) and 5.7\% DM (Radames). The fat content in white lupin seeds was significantly higher as compared to other species and ranged from 10.2 to $10.8 \%$ DM. It was shown that the fat level was negatively correlated with ADF content $(\mathrm{r}=-0.687 ; \mathrm{P}<0.05)$ of these species. Narrow-leaved lupin cultivars did not differ in their fat content; it ranged from 5.5 (Saturn) to $6.8 \% \mathrm{DM}$ (Emir) and was similar to that of yellow lupins. As raported by others, lupin oil is mainly composed of unsaturated long-chain fatty acids; oleic, linoleic and $\alpha$-linolenic acids dominated among them (Green and Oram, 1983; Lampart-Szczapa et al., 1994).

\section{Fibre fractions}

The crude fibre content of yellow lupin seeds was relatively high and ranged from 15.8 to $17.3 \%$ DM. The highest NDF $(26.8 \%)$, ADF $(21.7 \%)$ and ADL $(2.8 \%)$ contents were found in the cultivar Manru. Greatest variations in fibre fractions among years of cultivation was observed for Popiel. A positive correlation ( $r=0.915, r=0.906 ; P<0.01)$ was found between the content of crude fibre and either the NDF or ADF content. The level of fibre fractions did not differ significantly among cultivars within each lupin species. In white lupin cultivars the crude fibre content varied from 13.0 in Hetman to $15.6 \% \mathrm{DM}$ in Wat. In narrow-leaved lupins the level of fibre fractions were slightly higher in Sur than in Saturn, Emir and Polonez. A positive correlation was found between crude fibre and both the NDF and ADF content $(r=0.917, r=0.847 ; \mathrm{P}<0.01)$. Among three lupin species, no significant differences were observed in the content of fibre fractions, with the exception for crude fibre, the level of which was lower for white than for yellow lupin $(\mathrm{P}<0.05)$. Similar content of NDF and ADF in yellow lupins was found by Flis (1993) and in white lupin seeds by Robinson and McNiven (1993). Positive correlations between NDF and ADF content were found in yellow $(\mathrm{r}=0.875 ; \mathrm{P}<0.01)$ and of narrow-leaved lupin seeds $(\mathrm{r}=0.795 ; \mathrm{P}<0.05)$.

Ash

The crude ash content in yellow lupin cultivars, ranged from 5.1 to $5.7 \% \mathrm{DM}$ and was significantly greater than in seeds of white lupins (4.0-4.6\%) and in those of narrow-leaved cultivars $(3.9-4.3 \% \mathrm{DM})$.

Mineral composition expressed in $\mathrm{g}$ or $\mathrm{mg}$ per $\mathrm{kg}$ DM of lupin cultivars is summarized in Table 3 . The figures are means of three successive years of lupin seed analyses. 
TABLE 3

Mineral composition of lupin cultivars harvested in 1991-1994

\begin{tabular}{|c|c|c|c|c|c|c|c|c|c|c|}
\hline \multirow[t]{2}{*}{ Cultivars } & \multirow[t]{2}{*}{ DM } & $\mathrm{Ca}$ & K & $\mathrm{P}$ & $\mathrm{Mg}$ & $\mathrm{Na}$ & $\mathrm{Fe}$ & $\mathrm{Mn}$ & $\mathrm{Zn}$ & $\mathrm{Cu}$ \\
\hline & & \multicolumn{4}{|c|}{$\mathrm{g} / \mathrm{kg} \mathrm{DM}$} & \multicolumn{5}{|c|}{$\mathrm{mg} / \mathrm{kg} \mathrm{DM}$} \\
\hline \multicolumn{11}{|c|}{ Lupinus luteus: } \\
\hline Juno & 89.8 & 2.4 & 14.0 & 8.9 & 3.1 & 89 & 90 & 50 & 78 & 8.7 \\
\hline SD & & 0.1 & 0.55 & 0.2 & 0.0 & 5 & 11 & 22 & 6 & 2.20 \\
\hline Popiel & 89.4 & 2.8 & 12.6 & 7.9 & 2.8 & 103 & 93 & 102 & 86 & 11.8 \\
\hline $\mathrm{SD}$ & & 0.0 & 2.60 & 1.9 & 0.3 & 23 & 6 & 35 & 8 & 2.70 \\
\hline Amulet & 89.8 & 3.2 & 12.4 & 7.7 & 3.6 & 98 & 85 & 37 & 74 & 10.0 \\
\hline SD & & 0.9 & 1.59 & 0.5 & 0.8 & 3 & 7 & 11 & 14 & 0.50 \\
\hline Radames & 89.6 & 3.8 & 13.3 & 8.8 & 3.0 & 99 & 80 & 70 & 82 & 10.5 \\
\hline SD & & 0.7 & 1.69 & 1.3 & 0.1 & 22 & 11 & 51 & 13 & 4.33 \\
\hline Cybis & 90.2 & 3.4 & 12.0 & 7.6 & 3.6 & 111 & 128 & 48 & 76 & 10.0 \\
\hline SD & & 1.1 & 1.10 & 0.9 & 1.1 & 17 & 21 & 36 & 12 & 196 \\
\hline Manru & 90.0 & 4.3 & 12.3 & 7.6 & 2.6 & 79 & 99 & 85 & 72 & 8.9 \\
\hline $\mathrm{SD}$ & & 0.8 & 1.18 & 0.7 & 0.3 & 33 & 9 & 15 & 8 & 0.50 \\
\hline \multicolumn{11}{|c|}{ Lupinus albus: } \\
\hline Hetman & 90.9 & 3.9 & 11.8 & 5.0 & 2.1 & 96 & 63 & 828 & 46 & 5.7 \\
\hline SD & & 1.7 & 0.55 & 0.4 & 0.7 & 13 & 20 & 490 & 15 & 0.5 \\
\hline Bardo & 90.3 & 3.5 & 11.5 & 4.4 & 1.7 & 126 & 53 & 742 & 47 & 5.7 \\
\hline SD & & 0.6 & 1.60 & 0.4 & 0.1 & 35 & 2 & 254 & 7 & 2.1 \\
\hline Wat & 92.4 & 3.3 & 12.4 & 5.0 & 2.0 & 134 & 62 & 447 & 50 & 6.7 \\
\hline SD & & 0.4 & 2.10 & 1.2 & 0.0 & 20 & 2.5 & 47 & 3 & 3.2 \\
\hline \multicolumn{11}{|c|}{ Lupinus angustifolius: } \\
\hline Emir & 91.6 & 3.1 & 12.3 & 5.2 & 1.9 & 97 & 84 & 54 & 43 & 5.8 \\
\hline SD & & 0.7 & 0.10 & 0.1 & 0.3 & 18 & 20 & 24 & 1.9 & 1.10 \\
\hline Sur & 90.8 & 3.5 & 10.8 & 4.8 & 2.1 & 90 & 63 & 58 & 43 & 5.7 \\
\hline SD & & 0.1 & 0.10 & 0.1 & 0.1 & 20 & 3 & 34 & 1.5 & 0.60 \\
\hline Saturn & 91.3 & 4.3 & 10.3 & 4.6 & 2.8 & 112 & 61 & 26 & 37 & 3.4 \\
\hline SD & & 1.0 & 0.30 & 0.0 & 0.5 & 14 & 7 & 12 & 3 & 0.06 \\
\hline Polonez & 92.4 & 2.9 & 10.6 & 5.1 & 2.0 & 79 & 39 & 29 & 33 & 3.5 \\
\hline $\mathrm{SD}$ & & 0.6 & 1.13 & 0.2 & 0.4 & 41 & 6 & 17 & 1 & 0.14 \\
\hline
\end{tabular}

TABLE 4

Mineral composition of sccds of threc lupin species harvested in 1991-1995

\begin{tabular}{|c|c|c|c|c|c|c|c|c|c|c|}
\hline \multirow[t]{2}{*}{ Species } & \multirow[b]{2}{*}{$n$} & $\mathrm{Ca}$ & $\mathrm{K}$ & $\mathrm{P}$ & $\mathrm{Mg}$ & $\mathrm{Na}$ & $\mathrm{Fe}$ & $\mathrm{Mn}$ & $\mathrm{Zn}$ & $\mathrm{Cu}$ \\
\hline & & \multicolumn{4}{|c|}{$\mathrm{g} / \mathrm{kg} \mathrm{DM}$} & & \multicolumn{4}{|c|}{$\mathrm{mg} / \mathrm{kg} \mathrm{DM}$} \\
\hline L. luteus & 18 & 3.3 & $12.8^{c}$ & $8.1^{\mathrm{b}}$ & $3.1 \mathrm{~b}$ & 96.4 & $95.7^{b}$ & $65.2^{\mathrm{a}}$ & $77.9^{b}$ & $10.0^{\mathrm{b}}$ \\
\hline L. albus & 9 & 3.6 & $11.9^{\mathrm{ab}}$ & $4.8^{\mathrm{a}}$ & $1.9^{:}$ & 118.7 & $59.2^{a}$ & $672.3^{b}$ & $47.8^{i}$ & $6.1^{\mathrm{it}}$ \\
\hline L. angustifolius & 12 & 3.4 & $11.0^{\mathrm{a}}$ & $4.9^{\prime \prime}$ & $2.0^{\mathrm{a}}$ & 94.5 & $61.7^{a}$ & $41.8^{\circ}$ & $39.1^{4}$ & $4.6^{4}$ \\
\hline
\end{tabular}

a, b, c $-\mathrm{P}<0.05$ 
No significant differences were found among cultivars of any lupin species including the modern and older type cultivars, which suggests that the content of minerals depends rather on fertilization and soil properties than on genetic factors. In all tested cultivars potassium was a dominant macroelement (10.3-14.0 g/ $\mathrm{kg} \mathrm{DM})$.

An interspecies comparison (Table 4) showed that yellow lupin seeds contained significantly more $\mathrm{K}, \mathrm{P}, \mathrm{Fe}, \mathrm{Zn}$ and $\mathrm{Cu}$ than seeds of white and narrow-leaved lupins, concomitantly with their ash level (Table 1). However, the greatest differences among species were observed in the Mn content. Its level in white lupin cultivars ranged widely from 447 to $828 \mathrm{mg} / \mathrm{kg}$ DM. Its content was much lower (up to $102 \mathrm{mg} / \mathrm{kg}$ ) of other lupin species seeds. The present results are in agreement with those of Zduńczyk and Flis (1997) who determined up to $830 \mathrm{mg} / \mathrm{kg}$ DM of Mn in white Polish lupins. Even higher levels of Mn were reported by Gross (1984) and Gross et al. (1994) for Multolupa and Astra white lupin seeds containing, per kg DM 1.42 and $1.27 \mathrm{~g}$ of this mineral, respectively.

\section{Amino acids}

Amino acid composition (Table 5), except tryptophan, did not differ among yellow lupin cultivars. It was found that protein of Radames contained significantly more tryptophan $(0.90 \mathrm{~g} / 16 \mathrm{~g} \mathrm{~N})$ than that of other varieties $(0.76-0.80 \mathrm{~g} / 16 \mathrm{~g} \mathrm{~N})$. Among white lupin varieties, protein of Wat lupin contained more $(\mathrm{P}<0.05)$ lysine (5.15) and threonine (3.93) than protein of Hetman $(4.71$ and $3.60 \mathrm{~g} / 16 \mathrm{~g} \mathrm{~N}$, respectively). Significant differences in the content of some amino acids were also found among narrow-leaved varieties: protein of Emir and Sur contained more threonine and less glutamic acid and serine than protein of Saturn and Polonez. Protein amino acid composition of newly bred cultivars, such as Hetman, Saturn and Polonez was found to be less favourable than of other varieties of each species. Comparison of amino acid composition of protein of the species (Table 6) shows small but significant interspecific differences in nonessential and essential amino acids content, except lysine, methionine and phenylalanine. The most important difference was the highest cystine content and consequently its proportion in the sum of sulphur amino acids and relatively lowest threonine and isoleucine content in yellow lupin. Also, substantially greater tryptophan content was found in protein of narrow-leaved lupin than of the other two species. Comparatively, the highest threonine, tyrosine and isoleucine content in white lupin protein is in agreement with values found by Green and Oram (1983).

It was found that lysine $(r=-0.594)$, cystine $(r=-0.542)$, and isoleucine $(r=-0.483)$ content of yellow lupin protein, and threonine of white $(r=-0.713)$ and of narrow-leaved lupin $(\mathrm{r}=-0.645)$ were negatively correlated with the protein level. A negative correlation between the same amino acids and protein was 


\begin{tabular}{|c|c|c|c|c|c|c|c|c|c|c|c|c|c|}
\hline \multicolumn{14}{|c|}{ Mean amino acid composition of lupin cultivars harvested in $1991-1994, \mathrm{~g} / 16 \mathrm{~g} \mathrm{~N}$} \\
\hline \multirow[t]{2}{*}{ Indices } & \multicolumn{6}{|c|}{ Lupinus luteus } & \multicolumn{3}{|c|}{ Lupinus albus } & \multicolumn{4}{|c|}{ Lupinus angustifolius } \\
\hline & Juno $I$ & Popiel & Amulct & Radames & Cybis & Manru 1 & Hetman & Bardo & Wat & Emir & Sur & Saturn $\mathrm{F}$ & Polonez \\
\hline $\mathrm{Nx} 6.25, \% \mathrm{DM}$ & 42.5 & 44.1 & 44.4 & 42.2 & 44.1 & 43.6 & 37.4 & 35.1 & 30.7 & 32.5 & 31.6 & 34.6 & 34.10 \\
\hline Lys & 5.01 & 4.92 & 5.03 & 5.00 & 4.97 & 5.03 & $4.71^{\mathrm{a}}$ & $4.97^{\mathrm{ab}}$ & $5.15^{b}$ & 4.94 & 4.99 & 4.91 & 4.87 \\
\hline Met & 0.70 & 0.75 & 0.68 & 0.70 & 0.68 & 0.71 & 0.70 & 0.80 & 0.79 & 0.79 & 0.80 & 0.68 & 0.60 \\
\hline Cys & 2.18 & 2.11 & 2.21 & 2.31 & 2.26 & 2.15 & 1.80 & 1.65 & 1.65 & 1.64 & 1.72 & 1.68 & 1.54 \\
\hline Thr & 3.12 & 3.15 & 3.22 & 3.25 & 3.21 & 3.22 & $3.60^{\mathrm{a}}$ & $3.78^{\mathrm{ab}}$ & $3.93^{\mathrm{b}}$ & $3.63^{b}$ & $3.61^{\mathrm{b}}$ & $3.43^{\mathrm{a}}$ & a $3.43^{\mathrm{a}}$ \\
\hline Trp & $0.79^{\mathrm{ab}}$ & $0.76^{\mathrm{a}}$ & $0.76^{\mathrm{a}}$ & $0.90^{\mathrm{c}}$ & $0.85^{\text {be }}$ & $0.80^{\mathrm{ab}}$ & 0.68 & 0.79 & 0.82 & 0.94 & 0.93 & 0.81 & 0.88 \\
\hline Ile & 3.80 & 3.81 & 3.79 & 3.88 & 3.75 & 3.80 & 4.32 & 4.30 & 4.56 & 4.07 & 4.04 & 4.21 & 4.22 \\
\hline Arg & 11.20 & 11.20 & 10.84 & 10.41 & 10.66 & 10.78 & 9.85 & 10.28 & 9.19 & 10.36 & 10.62 & 10.57 & 10.80 \\
\hline $\mathrm{His}$ & 2.65 & 2.67 & 2.76 & 2.70 & 2.75 & 2.69 & 2.31 & 2.34 & 2.31 & 2.79 & 2.76 & 2.85 & 2.76 \\
\hline Leu & 7.58 & 7.56 & 7.66 & 7.64 & 7.60 & 7.45 & 7.50 & 7.45 & 7.80 & 7.05 & 7.10 & 7.20 & 6.96 \\
\hline Phe & 2.84 & 3.88 & 3.71 & 3.94 & 4.06 & 3.89 & 4.04 & 3.98 & 4.19 & 3.95 & 3.93 & 4.16 & 4.04 \\
\hline Val & 3.57 & 3.61 & 3.59 & 3.60 & 3.60 & 3.60 & 4.06 & 4.20 & 4.43 & 4.18 & 4.17 & 4.02 & 4.03 \\
\hline Ala & 3.07 & 3.08 & 3.14 & 3.16 & 3.13 & 3.16 & 3.28 & 3.40 & 3.63 & 3.54 & 3.58 & 3.41 & 3.37 \\
\hline Asp & 9.70 & 9.92 & 9.73 & 9.71 & 9.77 & 9.76 & 10.49 & 10.48 & 11.02 & 9.71 & 9.71 & 9.86 & 10.13 \\
\hline Glu & 24.32 & 24.26 & 25.10 & 25.11 & 24.98 & 24.31 & 23.01 & 21.61 & 22.54 & $21.92^{\mathrm{a}}$ & $22.08^{\mathrm{a}}$ & $24.16^{b}$ & b $24.21^{b}$ \\
\hline Gly & 3.69 & 3.74 & 3.85 & 3.86 & 3.81 & 3.81 & 3.93 & 4.01 & 4.16 & 4.32 & 4.29 & 4.22 & 4.18 \\
\hline Pro & 3.78 & 3.84 & 3.81 & 3.77 & 3.81 & 3.77 & 3.97 & 4.16 & 4.31 & 4.16 & 4.11 & 4.08 & 4.08 \\
\hline Ser & 4.66 & 4.68 & 4.72 & 4.75 & 4.74 & 4.67 & 5.13 & 5.00 & 5.30 & $4.59^{a}$ & $4.61^{\circ}$ & $4.85^{b}$ & b. $4.94^{b}$ \\
\hline Tyr & 2.67 & 2.72 & 2.57 & 2.72 & 2.80 & 2.80 & 4.31 & 4.36 & 4.46 & 3.44 & 3.37 & 3.52 & 3.51 \\
\hline
\end{tabular}


TABLE 6

Amino acid composition of seeds of three lupin species harvested in 1991-1995, $\mathrm{g} / 16 \mathrm{~g} \mathrm{~N}$

\begin{tabular}{lccc}
\hline Indices & $\begin{array}{c}\text { L. luteus } \\
\mathrm{n}=18\end{array}$ & $\begin{array}{c}\text { L. albus } \\
\mathrm{n}=9\end{array}$ & $\begin{array}{c}\text { L. angustifolius } \\
\mathrm{n}=12\end{array}$ \\
\hline Nx6.25, \%DM & $43.5^{\mathrm{b}}$ & $34.4^{\mathrm{a}}$ & $32.9^{\mathrm{a}}$ \\
Lys & 4.99 & 4.94 & 4.95 \\
Met & 0.70 & 0.76 & 0.72 \\
Cys & $2.21^{\mathrm{b}}$ & $1.70^{\mathrm{a}}$ & $1.65^{\mathrm{a}}$ \\
Thr & $3.19^{\mathrm{a}}$ & $3.77^{\mathrm{c}}$ & $3.56^{\mathrm{b}}$ \\
Trp & $0.81^{\mathrm{a}}$ & $0.76^{\mathrm{a}}$ & $0.89^{\mathrm{b}}$ \\
Ile & $3.80^{\mathrm{a}}$ & $4.39^{\mathrm{c}}$ & $4.14^{\mathrm{b}}$ \\
Arg & $10.84^{\mathrm{b}}$ & $9.78^{\mathrm{a}}$ & $10.40^{\mathrm{ab}}$ \\
His & $2.70^{\mathrm{b}}$ & $2.32^{\mathrm{a}}$ & $2.80^{\mathrm{c}}$ \\
Leu & $7.58^{\mathrm{b}}$ & $7.58^{\mathrm{b}}$ & $7.08^{\mathrm{a}}$ \\
Phe & $3.72^{\mathrm{b}}$ & 4.07 & 4.01 \\
Val & $3.59^{\mathrm{a}}$ & $4.23^{\mathrm{b}}$ & $4.12^{\mathrm{b}}$ \\
Ala & $3.12^{\mathrm{a}}$ & $3.44^{\mathrm{b}}$ & $3.47^{\mathrm{b}}$ \\
Asp & $9.77^{\mathrm{a}}$ & $10.67^{\mathrm{b}}$ & $9.76^{\mathrm{a}}$ \\
Glu & $24.70^{\mathrm{b}}$ & $22.39^{\mathrm{a}}$ & $22.72^{\mathrm{a}}$ \\
Gly & $3.79^{\mathrm{a}}$ & $4.03^{\mathrm{b}}$ & $4.28^{\mathrm{c}}$ \\
Pro & $3.79^{\mathrm{a}}$ & $4.14^{\mathrm{b}}$ & $4.12^{\mathrm{b}}$ \\
Ser & $4.70^{\mathrm{a}}$ & $5.14^{\mathrm{b}}$ & $4.75^{\mathrm{a}}$ \\
Tyr & $2.71^{\mathrm{a}}$ & $4.38^{\mathrm{c}}$ & $3.46^{\mathrm{b}}$ \\
\hline $\mathrm{a}$ & & &
\end{tabular}

a, b, c $-\mathrm{P}<0.05$

also reported for other leguminous seeds (Evans and Butler, 1980; Reichert and McKenzie, 1982; Gdala et al., 1992).

In spite of rather uniform lysine, methionine and tryptophan contents of protein of three lupin species, the nutritional value of yellow lupin as a source of protein supplementing cereal proteins may be lower because of relatively low threonine content. Tests with rats (Wasilewko et al., 1995) showed that methionine is the first limiting amino acid in all lupins protein, while the second limiting one depends on the species.

\section{Alkaloids}

Quinolizidine alkaloids are the main lupin antinutritional factors. Their content (Table 7) ranged from 600 (Hetman) to $950 \mathrm{mg} / \mathrm{kg}$ DM (Wat) in white lupin seeds. Much lower alkaloid level, from 300 (Saturn) to $510 \mathrm{mg} / \mathrm{kg}$ DM (Sur) was found in narrow-leaved lupin. The level of quinolizidine alkaloids and gramine (an indol alkaloid) in yellow lupin seeds ranged from 230 (Juno) to $1300 \mathrm{mg} / \mathrm{kg}$ (Popiel). Erickson 
TABLE 7

Alkaloids content in choiced lupin cultivars, $\mathrm{mg} / \mathrm{kg}$ DM

\begin{tabular}{|c|c|c|c|}
\hline \multirow[b]{2}{*}{ Lupin } & \multirow[b]{2}{*}{ Harvest year } & \multicolumn{2}{|r|}{ Alkaloids } \\
\hline & & sum & proportions \\
\hline \multicolumn{4}{|c|}{ Lupinus albus } \\
\hline Wat & 1991 & 950 & lupanine $>13$-hydroxylupanine $>$ multiflorine \\
\hline Bardo & 1991 & 790 & lupanine $>13$-hydroxylupanine $>$ multiflorine \\
\hline Hetman & 1992 & 600 & lupanine $>13$-hydroxylupanine, seco-12,13-didehydromultiflorine \\
\hline Hatman & 1994 & 866 & lupanine > hydroxymultiflorine, hydroxylupanine, multiflorine \\
\hline \multicolumn{4}{|c|}{ Lupinus angustifolius } \\
\hline Sur & 1991 & 510 & lupanine $>$ 13-hydroxylupanine \\
\hline Emir & 1991 & 440 & lupanine $>13$-hydroxylupanine, seco-12,13-didehydromultiflorine \\
\hline Helios & 1991 & 400 & lupanine, 13-hydroxylupanine \\
\hline Saturn & 1991 & 300 & lupanine, 13-hydroxylupanine \\
\hline Saturn & 1994 & 440 & lupanine, 13-hydroxylupanine \\
\hline \multicolumn{4}{|c|}{ Lupinus luteus } \\
\hline Juno & 1991 & 230 & lupinine $>$ gramine $>$ sparteine \\
\hline Popiel & 1991 & 1300 & gramine $>$ sparteine $>$ lupinine \\
\hline Cybis & 1992 & 510 & gramine, lupinine $>$ sparteinc \\
\hline
\end{tabular}

(1988), who analysed the lupin alkaloids obtained similar values expresed per $\mathrm{kg}$ of seeds: $900 \mathrm{mg}$ for white lupin Nyirsegi, $1100 \mathrm{mg}$ for yellow lupin Bortula and 100 mg for narrow-leaved lupin Unicrop. The main alkaloids in white and narrow-leaved lupin seeds are lupanine and 13-hydroxylupanine in yellow lupin seeds are lupinine, gramine and sparteine. There is a correlation between the level of lupin alkaloids and the level of rainfall during plant flowering (Christiansen et al., 1996); dry weather significantly increased the level of lupin alkaloids. Similar tendency for alkaloids in white (Hetman) and narrow-leaved (Saturn) lupin seeds was observed in the present study. Generally, higher level of alkaloids are given by Matyka et al. (1997) than found in this study for the home-grown lupin seeds.

\section{CONCLUSIONS}

Three lupin species differ in content of components affecting nutritional value of their seeds. The chemical composition of seeds depend primarily on the species and less on the cultivar and year of harvest. The good knowledge about the seeds of each lupin species/varieties is essential to choose the best lupin as a protein source increasing the production of farm animals. 


\section{REFERENCES}

Aniszewski T., 1993. Nutritive quality of the alkaloid - poor Washington lupin (Lupinus polyphyllus Lindl var. SF/TA) as a potential protein crop. J.Sci. Food Agric. 61, 409-421

AOAC, 1990. Official Methods of Analysis of the Association of Official Analytical Chemists. 15th Edition. Chapter 32. Washington, DC

Brollouet J.M., Riochet D., 1983. Cell wall polysaccharides and lignin in cotyledons and hulls of seeds from various lupin (Lupinus L.) species. J. Sci. Food Agric. 34, 861-868

Buraczewska L., Buraczewski S., 1981. A note on the determination of methionine and tryptophan. Proceeding of 6th International Symposium on Amino Acids, Serock (Poland), pp. 47-50

Christiansen J.L., Buskov S., Jornsgard J., 1996. Effect of drought stress on seed alkaloid content in Lupinus angustifolius. Proceeding of 8th International Lupin Conference, California, p. 24

Erickson J., 1988. Nutrition of pigs fed lupin. Proceeding of the $5^{\text {th }}$ International Lupin Conference, Po7nań (Poland), pp. 373-382

Evans M., Boutler D., 1980. Crude protein and amino acid content of some commercial varieties of peas and beans. J. Sci. Food Agric. 31, 238-242

Flis M., 1993. Nutritive value for pigs of the seeds of new faba bean and yellow lupin varieties (in Polish). Acta Acad. Agric. Tech. Olst., Zoot. 38, Suppl. A, 1-48

Gdala J., Buraczewska L., Grala W., 1992. The chemical composition of diffrent types and varieties of pea and digestion of their protein in pigs. J.Anim. Feed Sci. 1, 71-79

Green A.G., Oram R.N., 1983. Variability for protein and oil quality in Lupinus albus. Anim. Feed Sci. Technol. 9, 271-282

Gross R., Auslitz J., Schramer P., Payer H.D., 1984. Concentration of lead, cadmium, mercury and other elements in seeds of Lupinus mutabilis and other legumes. Intern. Lupin Conference, La Rochelle (France), pp. 385-396

Gross R., 1988. Lupins in human nutrition. International Lupin Conference, Poznań (Poland), pp. $51-63$

Hill G.H., 1977. The composition and nutritive value of lupin seed. Nutr. Abstr. Rev., B 47, $511-529$

Lampart-Szczapa E., Nogala-Kałucka M., Gogolewski M., Zawirska-Wojtasiak R., 1994. Nutritive value of oil some Polish varieties of sweet lupin (in Polish). Proceeding of the 1 th Conference "Lubin-Białko-Ekologia", Poznań (Poland), pp. 156-160

Matyka S., Korol W., Jaśkiewicz T., Bielecka G., 1997. Chemical composition and nutritive value of legume seeds (in Polish). Central Laboratory of Feed Industry, Lublin (Poland)

Pagowska E., 1990. Yellow lupin, narrow-leaved lupin, white lupin - Results of comparative evaluation of varieties (in Polish). Editor: Research Center of Cultivar Testing, Słupia Wielka (Poland)

Pagowska E., 1993. Yellow lupin, narrow-leaved lupin -- Results of comparative evaluation of varieties (in Polish). Editor: Research Center of Cultivar Testing, Słupia Wielka (Poland)

Philips Scientific Atomic Absorption Data Book, 1988. Philips Scientific, England

Reichert R., McKenzie S.L., 1982. Composition of peas (Pisum sativum) varying widely in protein content. J. Agric. Food Chem. 30, 312-317

Robinson P.H., McNiven M.A., 1993. Nutritive value of raw and roasted sweet white lupins (Lupinus albus) for lactating dairy cows. Anim. Feed Sci. Technol. 43, 275-290

Statgraphics Plus ver. 7.0, 1993. Statistical Graphics System by Graphics Corporation

Swięcicki W., Swięcicki W.K., Wiatr K., 1997. History, contemporary achievements and perspectives in breeding grain legumes in Poland (in Polish). Zesz. probl. Post. Nauk rol. No 446, 15-32

Wasilewko J., Pastuszewska B., Ochtabińska A., Buraczewska L., 1995. Amino acid composition and biological value of the proteins of three lupin species. Proceeding of the 2nd European Conference on Grain Legumes, Copenhagen (Denmark), pp. 273 
Van Soest P.J., 1973. Collaborative study of acid detergent fiber and lignin. J. Assoc. Agric. Chem. $56,781-782$

Van Soest P.J., Wine R.H., 1967. Use of detergents in the analysis of fibrous feeds. IV. Determination of plant cell wall constituents. J. Assoc. Agric. Chem. 50, 513-530

Wysocka W., Brukwicki T., Jałoszyński R., Hoffman K., 1989. A new and efficient method of extraction of alkaloids from lupin seeds. Lupin Lett. 13, 59-65

Zduńczyk Z., Flis M., 1997. Mineral composition of lupin seeds and biological effects of high manganese level in animal diets (in Polish). Proceeding of the 4th Conference Łubin-Białko-Ekologia", Olsztyn (Poland), pp. 229-243

\section{STRESZCZENIE}

Sklad chemiczny, w tym mineralny, aminokwasowy oraz zawartość alkaloidów w nasionach trzech uprawianych w Polsce gatunkach lubinu

Oznaczono skład chemiczny uwzględniając zawartość podstawowych składników pokarmowych, aminokwasów, związków mineralnych oraz alkaloidów nasion łubinu słodkicgo uprawianego w kraju. Materiał doświadczalny stanowiły nasiona 6 odmian łubinu żóltego (Lupinus luteus L.), 3 łubinu białego (Lupinus albus L.) i 4 odmian łubinu wąskolistnego (Lupinus angustifolius L.), które pochodziły $z$ trzyletnich zbiorów.

Stwierdzono, że w porównaniu $<$ pozostałymi dwoma gatunkami, nasiona łubinu żółtego zawierają więcej ( $\mathrm{P}<0,05)$ białka (ok. $44 \%$ s.m.), a w nim cystyny $(2,2 \mathrm{~g} / 16 \mathrm{~g} \mathrm{~N}$ ), nasiona lubinu białego są wiçksze (ok. $290 \mathrm{~g} / 1000)$ i zawierają więcej thuszczu (ok. $10,5 \% \mathrm{s.m}$.), treoniny $(3,8 \mathrm{~g} / 16 \mathrm{~g} \mathrm{~N}$ ), izoleucyny $(4,4 \mathrm{~g} / 16 \mathrm{~g} \mathrm{~N}$ ) i wielokrotnie więcej manganu (do ok. $830 \mathrm{mg} / \mathrm{kg} \mathrm{s.m}$.). Nasiona łubinu nie zawierają skrobi, a wśród węglowodanów nieskrobiowych dominuje frakcja NDF, która stanowi od 21,6 do $26,9 \%$ s.m. nasion. Głównymi czynnikami antyodżywczymi łubinu są alkaloidy. Ogólny ich poziom w wybranych analizowanych próbach nasion wynosił od 230 do $1300 \mathrm{mg} / \mathrm{kg} \mathrm{s.m}$. 